\title{
ON SIMON NELSON PATTEN'S PROGRESSIVISM: A NOTE.
}

\section{BY LUCA FIORITO AND MASSIMILIANO VATIERO *}

* University of Palermo - Studi europei e della integrazione internazionale and University of Trento Ringgold standard institution - Dipartimento di Economia e Management.

Address for correspondence: luca.fiorito.1967@gmail.com

This "preprint" is the peer-reviewed and accepted typescript of an article that is forthcoming in revised form, after minor editorial changes, in the Journal of the History of Economic Thought (ISSN: 1053-8372), issue TBA. Copyright to the journal's articles is held by the History of Economics Society (HES), whose exclusive licensee and publisher for the journal is Cambridge University Press (https://www.cambridge.org/core/journals/journal-of-the-history-ofeconomic-thought ). This preprint may be used only for private research and study and is not to be distributed further.

The preprint may be cited as follows:

Fiorito, Luca and Massimiliano Vatiero. On Simon Nelson Patten's Progressivism: A Note. Journal of the History of Economic Thought (forthcoming). Preprint at SocArXiv, osf.io/preprints/socarxiv 
1. Published just a few years ago, Thomas C. Leonard's Illiberal Reformers: Race, Eugenics, and American Economics in the Progressive Era (2016) is already considered a classic, and we cannot but agree with Bradley Bateman $(2017,718)$ that "the story of progressivism will never be told exactly the same way again after Leonard's book." ${ }^{1}$ Leonard employs the term "illiberal" in two distinct connections. First, he explains, the progressives saw themselves as rivals of nineteenthcentury liberalism, not simply in the sphere of economics but also in the arena of individual liberties and rights. Progressives aimed at social engineering on a vast scale, and, as educated experts, they saw themselves as an elite uniquely capable of transcending politics and objectively identifying the public good. Here Leonard (18-19) points out the inherent intellectual tension within a movement that, on the one hand, aimed (at least in appearance) at expanding and promoting democracy but, on the other, wanted to govern more through technocratic elites isolated from direct political accountability. Second, Progressive Era reformers were illiberal because virtually all of them promoted a form of scientific racism and eugenics based on their acceptance of three related concepts that he places at the core of the eugenic program: "the primacy of heredity, human hierarchy rather than human equality, and the necessarily illiberal idea that human heredity must be socially controlled" (109). None of these two charges is novel-both had been discussed in the existing literature on progressivism. ${ }^{2}$ The strength of Leonard's account is to be found in the way he blends them in a unified narrative. Leonard is far more willing than many of his predecessors to highlight how the progressives' embrace of "scientific authority" and their enthusiasm for expertguided control opened the door to policies of sterilization, eugenic planning, and racially-inspired support for immigration and labor restrictions.

\footnotetext{
${ }^{1}$ This book represents the culmination of Leonard's research on progressivism over the past several years. See, among others, Leonard 2003; 2005a; 2005b; 2009; 2011.

${ }^{2}$ Writing more than sixty years ago, for instance, Richard Hofstadter $(1955,20)$ noted that "somewhere along the way a large part of the Populist-Progressive tradition has turned sour, became illiberal and ill-tempered."
} 
Among the several protagonists of Leonard's narrative, Simon Nelson Patten represents a quite interesting case. Born in rural Illinois in 1852, the descendant of eighteenth-century Scots-Irish settlers in New York, Patten belongs to the first generation of American progressives-that of Richard T. Ely, Richmond Mayo-Smith, and Henry Carter Adams, just to name a few. In 1876, after spending eighteen months at Northwestern University, Patten, as did many other young American scholars of the time, went to Germany to pursue graduate study - at Halle, where he worked under Johannes Conrad. Earning his Ph.D. in 1878, he returned to the United States, and, unable to get a university position, he found employment as a secondary school teacher and administrator. Eventually hired by the University of Pennsylvania in 1888 , he became the preeminent figure of the Wharton School, the first business school affiliated with an American university. Patten played a crucial role in the changing professional context of the social sciences in late nineteenth- and early twentieth-century America. As a writer, he was as prolific as he was eclectic-his subject-matter included economics, history, psychology, biology, philosophy, and theology. As an academic "young Turk," he was an active cofounder of the American Economic Association, which he saw as "a protest not only against the narrow English economics but also against the current political and social ideas." ${ }^{3}$ As a charismatic teacher, he attracted to Wharton a whole array of devoted students, some of whom credited him with an impact far outlasting their college years. As a reformer, Patten can be considered in many respects as the standard bearer of Progressive-Era reform impetus to confront the difficulties brought on by rapid industrial and urban growth. As it will be discussed below, Patten's own brand of Progressivism saw the structural changes in American economy as signs of an emerging morality and social spirit that would lead to the reconstruction of American democracy along the new possibilities offered by an economic regime of "abundance."4

\footnotetext{
${ }^{3}$ Simon N. Patten to Richard T. Ely, October 22, 1909. Quoted in “Memorial to Former President Simon N. Patten" 1923, 260.

${ }^{4}$ See Dorfman 1949 and Fox 1967 for a full biographical account of Patten.
} 
Leonard (xiii) includes Patten in "[t]he roster of progressives who advocated exclusion of hereditary inferiors," and describes him as "quintessentially progressive in his social gospel impulses, his biologically informed social science, and his ambivalence toward the poor" (118). Patten's assertions that "[s]ocial progress is a higher law than equality, and a nation must choose it at any cost," and that the only way to progress is through the "eradication of the vicious and inefficient" $(1899,302)$, are reported by Leonard $(2003,654 ; 2016,199)$ as evidence of Patten's advocacy of "the substitution of social for natural selection of the fittest." Leonard (181) also enrolls Patten among the ranks of those who feared race suicide-the idea that immigrants with lower standards could outbreed their native betters--and quotes a passage from Patten where he observes, with approval, the social barriers "old stock" Americans had placed between them and the what they perceived as inferior classes and races. ${ }^{5}$ At the same time, however, Leonard detects an irreducible degree of ambivalence in Patten, noting that he swung like a pendulum between approval and disapproval of eugenics and its practices. In this connection, Leonard $(2011,457)$ points out that Patten "put somewhat less emphasis on inherited debility" than did some of his contemporaries like John R. Commons or Edward A. Ross, and that he "thus arrived at a less strenuously eugenic view of social reform." Ultimately, Leonard $(2016,119)$ asserts, "Patten's ongoing ambivalence about eugenics is perhaps a measure of the quintessential tension in progressive thinking, which simultaneously regarded the poor as victims deserving uplift and as threats requiring restraint." The situation is further complicated by Patten's own expository style, often fragmentary, obfuscating, and contradictory. As Ely (“Memorial to Former President Simon N. Patten" 1923, 263-264) observed long ago, "In going over his various writings, I have the feeling that no one of us really has a complete understanding of Patten, and no one can know the full force of his work until we have a systematic presentation of it as a whole."

\footnotetext{
${ }^{5}$ See our discussion below in section 6.
} 
This note is an attempt to offer a somewhat more comprehensive assessment of the main coordinates of Patten's progressivism through a systematic analysis of his writings. This will allow us to better delineate the differences-as well as the affinities-between Patten and the core of progressives discussed by Leonard. It is our contention that even within the persisting intricacies, ambiguities and contradictions of Patten's expository style it is possible to trace a shift in some aspects of his ideas - a gradual evolution which makes his peculiar brand of progressivism different from that of his most "illiberal" counterparts. Two preliminary considerations are worth making before launching into the discussion. First, this is by no means a complete analysis of Patten's economic and social thought. ${ }^{6}$ Our goal is far narrower, namely, to use the historiographic lenses proposed by Leonard and to explore in some detail Patten's views on individual rights, poverty and social efficiency, as well his ideas on eugenics, biological determinism, and immigration. Second, and more importantly, this note is not intended as a correction of Leonard's book nor an attempt to rescue Patten from being classified as an "illiberal" reformer. Leonard is quite clear in his identification of Patten as a special case, who often expressed an ambivalence about things about which other "illiberal reformers" seemed quite certain, and thus could not easily be pigeon-holed. This note should be rather seen as a reminder that, while Leonard has provided an enlightening account of some of the main intellectual currents of the time, we must remain aware of the rich variety of ideas that were flowing along beside, and interacting with, those main currents.

2. Patten's (often scattered and fragmentary) views on democracy and individual rights must be assessed against the background of his broader vision. Throughout most of his work, Patten saw

\footnotetext{
${ }^{6}$ It should be noted that other significant aspects of Patten's illiberalism discussed by Leonard, such as his apology of big business for overcoming the inefficiencies of market competition, his support of protectionism and his prohibitionist stance, won't be taken into consideration here.
} 
the economic and social inequality and the consequent class warfare which plagued contemporary America as the product of an historical transition from an economy of scarcity to one of abundance. Whereas in an age of scarcity, which he characterized as a "pain economy," individuals were engaged in a struggle for the basic necessities and comforts of life, the new age of abundance brought by the recent industrial advances had made the satisfaction of needs less pressing and therefore open to different kind of responses. In this new "pleasure economy," production is not only increased in quantity but, more crucially, is directed "into channels through which a greater variety of growing desires can be gratified" $(1889,38)$. The differentiation of desires, in turn, acts upon the "feelings and mental characteristics of men" (29-30), gradually leading to the weakening of selfish motives and the emergence of a new cooperating spirit among individuals. Patten leaves no doubt about the central role played by the evolution of consumption habits in the establishment and propagation of this regenerated sense of social cohesion:

In the same way other institutions would arise within the field of consumption, the end of which would be to correlate and harmonize the pleasures of each person better than it would be possible for him to do if he remained isolated. Family life, the church, the club, labor unions, trade organizations and a great variety of associations designed for special classes of men and for the gratification of particular desires, would spring up in a natural way, as soon as the needs, desires and temptations of social life became apparent. Each of these institutions would force those connected with them to modify their conduct in certain particulars and to acquire certain habits and modes of thought, which would fit them for the social life which the institution creates. $(1896,97)$ 
In the end, as Patten $(1902,236)$ put it, "the economic equilibrium working through desire tends to make all persons equal, independent and self-sustaining." Patten's views on trusts epitomizes this optimistic (almost utopian) stance. Like many of the progressives discussed by Leonard, Patten believed in the superior efficiency of large-scale, vertically integrated economic organizations-superior to that of uncoordinated market competition. To the (then standard) efficiency thesis, however, Patten added an interesting normative twist. The recent decade of industrial consolidation, he wrote $(1912 a, 28)$, has also brought about a profound "reorganization of our social sentiments." To Patten's eyes, the growth of large-scale capitalism had in fact resulted in the elimination of the "unsocial capitalist" and in the increasing control of each industry by a "socialized group" with an "intense, cooperative spirit." This new "sympathy for the laborer" among capitalists finds expression in the awareness that the satisfaction of desires in an evolved society is a process that "has changed from an antagonistic or individualistic form to one of voluntary cooperation" (71).

Why then, Patten $(1907,47)$ asked, do poverty and social unrest-"which ought to be disappearing from a rich and lavish world" - continue to exist and proliferate? His response was an early version of the cultural lag theory popularized by William F. Ogburn in the 1920s (Fox 1967; LaJeunesse 2010). In Patten's opinion, the frictions which prevented a full transition towards a pleasure economy were inherently social, rather than economic. Economic frictions-namely, those "maladjustment between men and nature, which forced men in the past to submit to a poverty they did not know" (1907, 68-69)-were in the process of being eradicated, "weakened by the application of knowledge, science, and skill." On the contrary, the inertia exercised by the social institutions established during a regime of scarcity continued to persist. These mental and behavioral patterns reflected "the passing age of nature's deficit" and are therefore totally unsuited to the new economic conditions. As Patten (11) put it in an oft-quoted passage, "[t]he economic 
revolution is here, but the intellectual revolution that will rouse men to its stupendous meaning has not done its work." "It is essential to recognize," Patten later insisted (1912a, 89), "that we have passed from one epoch to another and that our principles and facts must be correspondingly modified."

Within this framework, Patten advanced his own criticism of classical liberalism and its civil rights agenda. He was adamant in arguing that enlarging the sphere of civil or procedural rights was no longer a solution to protect the weaker segments of society. The idea of individual rights had originated in the specific historical context of the eighteenth century and could not be regarded as a universal moral imperative under the new industrial conditions. "The doctrine that every man counts for one," Patten wrote (1912a, 85-86), "checks aggression when applied to food and wages." In a context freed by the constraints of physical scarcity, however, it leads "to a pure individualism in which group action has no place." Society is changed "from an organism to a mob," thus inhibiting the "rise of social sentiment through which a higher unity comes." Patten did not present a systematic conceptualization of his democratic ideal, although in its general outlines his vision comes close to that of other progressive reformers. Like many of his German-trained fellows, he located the essence of individuality in its social dimension, so that the individual-the subject himself and not just his feelings and aspirations-is defined to some extent by the community of which he is a part (Schäfer 2000 and 2004). Upon these premises, political rights could only be meaningful as a basis for the active participation of the individual in the democratic construction of what he called "social consciousness"-i.e., the intrinsic knowledge of authentic and organic ties between individuals. In this connection, he regarded the intricate social network of industrial society as heralding a new form of community which would weaken the ties of class boundedness and antagonistic interests: 
Lying beyond the entrance into an intensive and interclass democracy, is a field of social consciousness containing pleasure and political clubs, lodges, secret societies, and labor organizations. Beyond this in a broader area of experimental and idealistic social democracy are the social settlements, the cooperative undertakings, and the societies of meliorists whose object it is to carry the economic and cultural opportunities from one extreme of society to the other. But these steps toward social consciousness are a less comprehensive movement toward unity than modern Industrial Unionism. Utilitarian in its motive, and passionately selfish in its singleness and intensity of purpose, it has a social and ethical significance that is without parallel in the institutions of democracy: it is the first coalition of the economic powers of the basal men and the high-grade, skilled workers. $(1907,103)$

The advent of this "intensive and interclass democracy," which Patten saw as the completing stage in the institutional transition from scarcity to abundance, would necessarily imply the definition of a new set of rights. Whereas the older political rights "were obtained by picturing a primitive society where men were so isolated that their relations were simple and plain," these new rights are "economic" in character, i.e. all tied, directly or indirectly, to guaranteeing a higher standard of life. As Patten $(1902,215)$ put it: "[f]reedom consists not merely of political rights, but is dependent upon the possession of economic rights, freely recognized and universally granted to each man by his fellow citizens." Patten organized these rights under four headings. The first are "Public or Market Rights," and include rights to an open market, to "publicity" (transparency in market transactions), to security, and to association. Among "Social Rights" are rights to a home, to personal development, to wholesome moral standards, to homogeneity of living standards, and to decisions by public opinion. Among "Rights to Leisure" are provisions to recreation, clean air and 
water, and a pleasing visual environment. Among "Exceptional Rights," Patten called for family provision in the event of unemployment or industrial accident, and (as we will discuss in detail below) for rights to an income both for single and married women. While a systematic discussion of each of these rights goes well beyond the scope of this note, there is a crucial aspect which is relevant to our discussion. Differently from some of his contemporaries, Patten held an inclusive, rather than exclusionary, notion of economic rights. Nowhere, in fact, did Patten attempt to draw a normative boundary between deserving and undeserving individuals-a then recurrent distinction based on whether poor individuals behave in ways that contribute to their poverty. In this connection, Patten (234) juxtaposed "social standards" and "rights." While the former often foster class warfare and social fragmentation, in the sense that they "are built up and maintained by the class that profit by them," the latter are "universal" in character and create social bonds.

3. Patten's advocacy for a new set of economic rights brings us directly to one of the most controversial aspects of his thought, namely, his views on poverty. In his characterization of the progressives, Leonard (2016, xii-xiii) points to what he considers the great contradiction at the heart of Progressive Era reform: "its view of the poor as victims deserving state uplift and as threats requiring state restraint." This tension, Leonard continues, resulted in an "unstable amalgam of compassion and contempt," which helps explain why "Progressive Era reform lent a helping hand ... while simultaneously narrowing that privileged circle by excluding the many it judged unworthy ... and did both in the name of progress." An analysis of Patten's passages on the causes of poverty reveals a net discontinuity in his thought.

In his early works, Patten perfectly adhered to the progressive ideal described by Leonard. In his first book, the controversial Premises of Political Economy (1885), Patten identified the 
efficiency of society with the encouragement of its productive elements and the elimination of the unfit. In this connection, he was concerned about the dysgenic consequences of technological advances. "Every introduction of machinery which displaces skilled labor," he warned (220), "increases the amount of the deficiencies which the laboring classes may possess without their being thereby overcome in the struggle for subsistence that the survival of the ignorant brings upon society."7 Just a few years later, in The Theory of Dynamic Economics (1892), Patten observed that modern industrial conditions impose a radical change in the rules that govern the struggle for existence. The emphasis, he affirmed (105), is shifted from the "gifts of nature and the differences in land" to "inherited mental qualities and differences in intelligence." Efficient production, therefore, results from the "possession of certain mental qualities rather than from the possession of superior natural forces," while the laws of distribution depend upon "differences in intelligence more than upon differences in land." Accordingly, poverty assumes a new form:

Viewed subjectively, the lower classes are shut out from the margin of enterprise because they lack those mental qualities needed to extend production into new fields. Those opportunities for employment which require the least intelligence are first utilized by society, and in the successive stages of its development the field of employment is gradually extended to those opportunities for employment which require more intelligence and a greater number of mental qualities These new opportunities are better opportunities, but they require a higher type of a man to utilize them. As the margin of enterprise rises the lowest classes in society are gradually shut out from the margin, and they are restricted to the older and more mechanical industries. In these occupations they must struggle for existence without that relief from

\footnotetext{
${ }^{7}$ As a solution, Patten $(1885,220)$ suggested for low skilled occupations the introduction of "such tests of intelligence and skill" to exclude "all classes below the average standard."
} 
competition which those secure to whom the margin of enterprise is free because of the possession of better industrial qualities. (105)

Patten (118-119), again, conceded that "if the sympathy for poverty is strong" among the higher classes, part of the "social surplus" generated by the new advances in production may be employed in the "vain endeavor" to sustain those who "lack the subjective qualities needed to make them valuable members of society." 8 This, however, would not be beneficial to progress, since it implies a subordination of "the interest of society to that of particular classes."

Some initial indications of a change in Patten's perspective appear in his The Theory of Prosperity (1902), where he introduced a semantic distinction between misery and poverty. According to Patten (2-3), whereas poverty derives from natural scarcity, misery is a form of "nonadjustment" due to a lack of correspondence between the goods which human effort produces and the "mental states" their use is supposed to create: "Effort produces goods, but goods do not create happiness." While poverty may be imputed to some "hereditable" characteristics of the individuals who suffer from it, misery could be only abolished if society would accept values and restraints appropriate to an age of abundance. In the words of Patten (41): "Misery is not a product of nature: it is man-made." Yet, this concession notwithstanding, he (176) continued to adhere to a deterministic view of progress in which "class after class of the unfit is ... cut off," and the "surviving portion to an increasing degree acquires the same qualities and habits." The only safeguards against social degeneration, he insisted, are the establishment of "natural standards" and a "natural elimination enforcing them."

\footnotetext{
${ }^{8}$ In his distribution theory Patten divided the total product of society into two funds. One fund was necessary to pay the costs of production - an amount great enough to offset the psychic pains involved in production - and the remainder represented what he called "the social surplus." See Hunt (1970) for a detailed discussion.
} 
It was in his New Basis of Civilization (1907), probably Patten's most influential book, that he fully abandoned the rigid identification of the poor with the unfit which he had proposed in his earlier works. There, he (169) explicitly attacked those thinkers who "hold rigidly to the doctrine that progress is the elimination of the unfit" and that "only the slow processes of centuries can graft the new characters that will raise human nature to a moral plane." No such evolution, Patten affirmed, has ever taken place-man's heredity has "changed in no marked degree by the course of civilization." Moreover, the social attitudes of modern societies are opposed to elimination: "We protect the weak instead of exposing them; we restrain the strong instead of giving them full power." Patten then continued offering a neat revision of his earlier views:

These general principles combined with the influences of class differentiation will surely check for generations, if not forever, the sharp elimination upon which animal evolution depends. But even if a development in character through contest should take place, and the strong characters be matched against the weak as animals meet each other in grim combat, it is not likely that the social qualities would survive when so pitted against the unsocial. From their very nature they are opposed to elimination and the suffering it entails. Sympathy must go out to succor the weak, charity must aid the poor, and justice the oppressed. Neighborliness and kind-heartedness thrive in the help that those in temporary distress give each other. Without these qualities we might have a superman with excellent adjustment to nature; but if this superman mocked the weak instead of saving them, his strength, excellence, and beauty would be those of an animal. (169171) 
Whereas in the past Patten $(1889,68)$ had argued that the aim of reform was "to shorten the period of transition" from an economy of scarcity to one of abundance, so to limit in time the inevitable consequences of progress on the weaker elements, he now advocated a new role for the "social worker" - a term he himself helped popularize. "When a social worker ... no longer searches for superman," Patten wrote $(1907,218)$, he soon realizes that "regeneration is prevented not by defects in personality, but by defects in the environment," and that "the subjective tests of character to which he has been accustomed" must be replaced by "objective standards which test the environment." In this connection, he rejected the "service altruism" of older philanthropists-a form of "paternal kindness" rooted in the old tradition of "social control" - for what he termed "income altruism," namely, a new form of "public generosity" which is "willing to bestow gifts without conditions" and "to be taxed for public and far-reaching ends." ${ }^{9}$ Income altruism, Patten explained, is a "moral impulse" promoting an egalitarian model of good citizenship based on the idea of cooperation between individuals sharing a common "standard" in an environment of expanding opportunities. "When income-altruism has socialized a capitalist and given him stronger motives than the dominating capitalist now has," he explained (85-86), "the cleavage between classes will become less distinct." Under these new conditions, "the instincts and emotions of all groups will become approximately alike but will find varied expression as the income changes."

And yet, Patten's style remained ambiguous and contradictory. In the New Basis of Civilization $(1907,52)$ he was still contrasting the "respectable poor" with "the vicious, the depraved and chronic paupers" who would scarcely benefit from any ameliorative reform. Even more crucially, Patten's reliance on income altruism did not make him immune to the inherent

\footnotetext{
${ }^{9}$ Patten $(1907,85-86)$ illustrated the difference between service and income altruism through the parable of the Good Samaritan: "The one crossed the road to help the Samaritan after he had suffered under bad conditions of highway management; the other patrols the road and arrests the wayside thieves before the traveller falls among them. Servicealtruism binds the wounds, breathes forgiveness, and solaces the victims of recurring disasters without attacking their causes."
} 
paternalism that tainted much of the literature on poverty of the period. We find in fact in Patten, as in many of his contemporaries, the firm belief that that the key to social progress lay in improving the values and preferences of certain classes, especially the lowest, so that they adopt the "right" standards of living. This, in turn, necessitated a technocratic elite, via arguments that social scientists could both identify what sorts of values and preferences led to pro-social behavior, and what sorts of social institutional arrangements helped give rise to those values and preferences. Strictly connected, then, was crucial the question of how much coercion was permissible in order to impose new social institutions on recalcitrant populations. Although Patten discussed these aspects only incidentally, there is little in his writings that would suggest the need for coercive control of the poorer classes. His stress on "income altruism" seems to suggest that if the poor were given the requisite material security, they would naturally come to develop the appropriate values and preferences, often by voluntarily forming and joining the requisite institutions. There was "social work" to be done to help this process along - and he did not hesitate to assert $(1907,199)$ that "the new civilization will be ready as soon as social work has been made a science" - but in Patten's view $(1907,211)$ these social workers were going to work mostly through persuasion and exhortation, not government backed coercion. ${ }^{10}$ Significantly, Patten (212-213) was critical of those reformers who "are urgent in transferring this body of practice to the poor in the hope that it will affect their lives as it has ours." As he stated in a following passage, "the aim of social work is democracy rather than culture." The only implicit coercion is coercion of the non-poor, that is, the new taxes they would have to pay to provide funds to be distributed to the poor. ${ }^{11}$ This appears to be yet a further

\footnotetext{
${ }^{10}$ In this connection, Patten placed much stress upon the educative power of urbanization-a "spontaneous" process inherent to the rapid industrialization of the day. He regarded city life not aa a potential "good" to be developed into an inspiring sense of commonality, in which a new pride and loyalty are to be fostered. Urban civilization, Patten explained $(1907,126)$, "points out where beauty exists in cooperative communal institutions, and fosters neighborhood pride and the spirit of association. Instead of restraining impulses and instincts, it seeks to free the imagination, to stir and spur the desires, and to concentrate pointless energies upon the coordination of man and city."

${ }^{11}$ As Patten $(1907,69)$ acknowledged, "there is no fire in the citizen's blood to illumine the nobility of paying higher taxes. He does it grumblingly, under compulsion, and he fights an increase of the rate with warm determination."
} 
distinction between Patten's ideas and those often found in the main currents of progressivism, which involved coercive social control of poor with the aid of government and even the exclusion from suffrage of entire segments of society.

4. We now turn to some receptions of Patten's later views on poverty among his contemporaries - a brief digression that allows us to better place his ideas within the broad context of progressivism. Patten's New Basis of Civilization, the book which marked his change in perspective, was received with mixed feelings. On the one hand, Columbia University's Edward T. Devine $(1907,135)$, a leading authority in the field of social work and a devoted disciple of Patten, referred to his mentor as the "ablest exponent of the new view of philanthropy."12 The philosophy permeating Patten's approach, Devine enthusiastically continued, is "more completely democratic" and "offers a sounder basis for rational optimism than we have discovered in the writings of any other defender or critic of existing conditions." The Chicago sociologist George E. Vincent (1907, 743) praised Patten for having called attention to the "inevitableness of readjustment" and for his "illuminating interpretations of our standards and ideals." To "conservative thinkers," Vincent prophetically stated, "Professor Patten's attempt to demonstrate a radically new social order will be hardly convincing."

On the other hand, Patten was the object of harsh criticism, both from within and outside academia. What concerns us here is that these attacks came from figures who in many respects epitomize the illiberal impulses Leonard detects in some currents of Progressive Era reform. One of these figures was Mary Richmond-who, together with Jane Addams, stood as the most influential social work professional of the period (Franklin 1986). In her The Good Neighbor in the Modern City

\footnotetext{
${ }^{12}$ Trained as an economist, Devine also served as head of the Charity Organization Society of New York and director of the New York School of Philanthropy.
} 
(1907) Richmond contested Patten's distinction between service and income altruism. Somewhat misinterpreting Patten's thought, she wrote:

Money power is here given as the distinguishing characteristic of effective charity. Income-altruism is indeed needed, but without a strong infusion of the service-altruism of which Professor Patten speaks slightingly, it never kept anything policed and lighted, never "hewed to the base" since the world began, and never will ... Money is a bad master but a good servant; it supplemented the neighborly service of the Samaritan in the parable, but was no substitute for it. And lacking his spirit to-day, we may spend money like water in our campaigns of prevention, and still make little headway. (17)

Richmond's criticism of Patten was actually based on a deeper gulf between the two authors. While Patten in 1907 had come to reject causal explanations between pauperism and individual reprehensibility of any sort, throughout her life Richmond firmly believed that deficiencies of character figured prominently among the causes of poverty (Boyer 1978). As she put it in her Friendly Visiting Among the Poor (1903, 8-9), "Character is at the very center of this complicated problem" of poverty, and the poor "are masters of their fate to a greater degree than they will recognize or than we will recognize for them." Neglect of "the importance of character," she added, was a "common fault of modern philanthropy." In her subsequent work, Social Diagnosis (1917), Richmond went a step further, embracing both the language and methods of eugenics. In discussing the main sources of diagnostic information, for instance, she pointed out that "school evidence must play an important part in the discovery and segregation of defectives" (234). In a similar vein, 
her assessment questionnaire for families in need of charity was grounded in an explicit focus on hereditarian fitness (Kennedy 2008). ${ }^{13}$

The most incisive attack on Patten, however, came from academia-namely, from Harvard's Thomas Nixon Carver, much likely the most conservative among Progressive Era economists. Carver was a devotee of eugenics, far more outspoken than Richmond, and a staunch supporter of the view that "all poverty is $\sin . .$. the consequence of thriftlessness, prodigality, intemperance, unchastity, even irreligion" - in the words of a contemporary observer such as Jacob Hollander $(1914,16) .{ }^{14}$ Carver's target was The Social Basis of Religion (1911), a book where Patten had cast in spiritual terms the views on poverty he had presented in The New Basis of Civilization. Specifically, Carver disagreed with Patten's $(1911,209)$ contention that, "As a plan of progress, religion emphasizes the incorporation of the weak into society," rather than its "elimination" in the competitive struggle. According to Patten, progress by elimination, which he opposed to progress by "redemption," would lead to the emergence of an "ideal of an unsocial superman," contrary to the Christian notion of "service." Only a "social plan of redemption," made now possible under a surplus economy, could complete the "work that Christ began" and that "could not be fully developed in the early centuries because of adverse economic conditions."

Redemption and elimination, Carver $(1911,792)$ rebutted in his harsh review of The Social Basis of Religion, "are not opposing but complementary processes." He went on to argue that

Progress through redemption is of course a real thing. They who had formerly loved evil and shunned good, they who have wasted their energy in vice, must be taught to love

\footnotetext{
${ }^{13}$ Richmond $(1917,379)$ recommended that the caseworker ask questions such as: "Did the parents or other relatives of the husband or wife have marked mental, moral, or physical defects?"; "What facts, if any, about the husband or wife or their parents would indicate physical or mental dangers to be guarded against or special capabilities to be developed in the children?"

${ }^{14}$ On Carver's economics and its relation to eugenics, see Levy, Peart, and Albert 2012 and Fiorito and Orsi 2017.
} 
good and shun evil, that is, to economize and apply their energy to socially productive purposes. But they who will not be redeemed, or who cannot be reached by evangelical appeal, who reject the call to the productive life, must be eliminated by the slow but sure process of economic competition. If they are preserved in spite of their unproductiveness, the doom which should be visited upon them will surely be visited among the social group, the nation, or the race whose system of morality, or whose religion, exercise itself to keep them alive, or to protect them against the normal results of competition. (792-793)

"If this rejection of the call to the productive life does not constitute the sin against the Holy Spirit," Carver (793) concluded, "it certainly produces exactly the same result, for there is no salvation from this sin." Patten replied to Carver with a note emblematically entitled "Theories of Progress," published the following year in the American Economic Review. Patten contrasted his own "economic" approach to Carver's "biological" interpretation of progress-the former is interested in "Race Progress," the latter is concerned with the process of "Social Adjustment." While Patten admitted some possible connection between these two approaches in the "ultimate adjustment to a distant Utopia," he denied any influence of the biological factor in the "actual adjustment" imposed by the transition from an economy of scarcity to one of abundance. "Americans can become adjusted to present America without race progress," he reiterated - such an adjustment is wholly "economic" in character, and "does not demand elimination or race evolution."15

\footnotetext{
${ }^{15}$ Carver did not further rejoin to Patten's reply but the same year he published The Religion Worth Having, a small volume intended for a popular audience. There, he reiterated, possibly in harsher terms, his biology-infused view of religion. "The only conception of a kingdom of God on earth which is possible to a person who believes that this physical world is God's world," he (1912, 76-77) stated, rests on the idea that "the laws of selection now in operation are God's laws." Accordingly, he continued, "the kind of a group which best meets the conditions and requirements of this world of struggle and survival ... must, of logical necessity, be God's kingdom."
} 
5. The issues raised by the Carver-Patten exchange lead us directly to Leonard's second element of illiberalism-namely, the progressives' embrace of eugenics and their faith in the importance of biology for social reform. Patten's opinions on eugenics, as Leonard documents (see also Fox 1967), are contradictory and often expressed in ambiguous terms. In 1911, for instance, he published in Survey a note to challenge the eugenicist claims of Frederick A. Woods, a biologist from MIT. ${ }^{16}$ Patten insisted that the most relevant of social and mental traits can be accounted for without assuming a change in man's innate characters. "All virtues and defects in men are environmental," he wrote (1911b, 401)-but in a subsequent passage he contradicted himself, affirming that "[h]eredity is the one power that can transform man into a superman and we must rely on it to reach this higher level." The following year, Patten (1912c, 273) contrasted the eugenicist's point of view with that of the social worker. The latter's mission "demands a saving of life," and this why "we find him engaged in the struggle to prolong life and to prevent the elimination the eugenist favors." "[C]rude elimination does not improve social conditions," Patten resolved. But then again, in his Reconstruction of Economic Theory (1912a, 81), he reversed his views, arguing that "the defective and delinquent classes must be segregated if they are to be eliminated and thus a place made for a better stock. The science of eugenics tells us how to proceed and sound reasoning makes plain the social uplift that would follow its application."

Patten's views on eugenics, contradictory as they certainly are, does not allow us to evaluate whether his concern over the biological quality of individuals evolved over time. A different way to assess Patten's ideas on this matter is to look at his discussion of the biological foundations of

\footnotetext{
${ }^{16}$ Woods $(1910,336)$ left no doubt as to his firm hereditarian stance: "Experimentally and statistically, there is not a grain of proof that ordinarily environment can alter the salient mental and moral traits in any measurable degree from what they were predetermined to be through innate influences."
} 
human behavior. Patten first discussed the topic in his The Theory of Social Forces (1896) and dealt with it more systematically in The Development of English Thought (1899) and Heredity and Social Progress (1903). His overall approach is both tortuous and phrased in a convoluted terminology and detains us here only in its main coordinates. Patten $(1899,1-2)$ moved from the assumption that the "mental process" by which men are adjusted to an environment is of a "dual nature." On the one hand, through "sensory powers" the external world is brought into the realm of men's consciousness. Sensory knowledge is dynamic and inherently cumulative. As a growing number of objects within the environment are named, classified and distinguished, more and more "sensory ideas" become interrelated and associated with each other: "[t]he greater the knowledge of the environment ..., the longer are the series of ideas and the stronger the probability that any one idea will be followed by all the others of its series." Through "motor powers," on the other hand, men react upon the external world on the basis of their sensory knowledge of the environment. While "action ... demands that the whole organism should respond to the exciting stimuli," Patten specified, not all sensory ideas trigger motor reactions. Only "vivid" ideas, namely, those related to "elements, objects and relations that are requisites for survival," afford the stimuli to human action. These ideas, in turn, become "so blended and unified" as to constitute what Patten calls "race ideals":

Race ideals, then, are the visualized groups of ideas which this peculiar development has created. Through this visualization the sensory side of the mind is brought into harmony with its motor side, and is made to emphasize objects and relations that can be made, through motor reactions, to contribute to the welfare of the individual and of society. Heredity thus creates both the ideals of a race, and the motor reactions through which they may be realized. National character depends not merely on the number of these 
motor reactions, but also on the vividness of the ideals towards which national activities are directed. (15-16)

Patten postulated that a perfect correspondence between race ideals and the requirements of a present environment could never be attained. "Character is formed by the long series of environments in which a race has lived," he (4) wrote. This means that most of the motor reactions that form a race ideal were created in the past under environmental conditions completely different from those of today; yet they persist over a certain amount of time because they are the result of a slow process of "hereditarian adjustment." In this connection, Patten changed his views as to the mechanism through which motor responses are transmitted. First, he (16) adhered to the Lamarckian idea that those acquired "motor mechanisms" which have survival value gradually become "instinctive," thus leading to "organic modifications" which pass from generation to generation. In Heredity and Social Progress (1903), instead, he proposed an alternative explanation, drawing upon a quite debatable reading of the work of August Weismann on cell growth. "Acquired characters are not inherited," Patten stated (23-24), but "the improved situation of parents who acquire characters gives to their children more vitality and better opportunities to develop their natural qualities" - this in turn results in "new qualities which the children utilize by a change of occupation or environment." In short, "every acquired quality increases energy, and the additional energy starts a movement toward a new environment."

Albeit then perceived to be based upon "false biological reasoning"-as one reviewer (Calkins 1903,541$)$ did not hesitate to point out -this explanation allowed Patten to tone down the biologically deterministic element in his theory. This is clearly revealed by his discussion of the then so-called "backward" or "lower" races. For Patten (184), "a backward race or class need not be radically altered to fit it for civilization." Races differ in their motor reactions, rather than in their 
sensory powers, and most of the necessary changes in race ideals "come of themselves if the initial evils are removed." The crucial factor is the liberation of "surplus energy," by which Patten meant the excess energy resulting from a satisfied state of the primary physical wants. ${ }^{17} \mathrm{New}$ racial traits arise from increased surplus energy, and with this a demand for a higher standard of life:

The development of a lower race-let us say the negroes in America-does not necessitate remaking the negro by an artificial process. Set free the series of natural changes, and the final results will take care of themselves. A surplus includes regeneration and new emotions, forces which will act and react until the whole class has been brought up to the level of its environment. Two races in one environment cannot be kept apart except by some exploitation that harms the weaker one of them. The amplest protection and a surplus yielding discipline will stimulate the forces in a lower class which will ultimately raise them to the level of the highest. Each new discipline yields a new surplus which offers emotion and regeneration a fresh opportunity to evoke natural qualities. $(1903,185-186)^{18}$

Once again, we have to stress that it would be an oversimplification to assert that Patten, even if he came to oppose racial reasoning, univocally embraced nurture over nature. His stance became less deterministic but still permeated by ambiguities and contradictions. In the Social Basis of Civilization (1907) we find him asserting that "character is acquired by example not by blood"

\footnotetext{
17 Patten $(1902,15)$ considers the creation of "surplus energy" a purely "physiological" process. In his view work is normally a pleasurable activity and becomes irksome only when the initial fund of surplus energy is exhausted. On the other hand, "Every increase of productive power adds to the quantity of goods consumed, and these if properly used augment the surplus energy of workers."

${ }^{18}$ To assess the significance of Patten's position we just need to compare it with those of his contemporaries who held that only crossbreeding would allow African Americans to rise up to the standards of the European American stock. See, among others, Bushee 1903 and Commons 1907.
} 
(215), and then, just a few pages away, saying that "vices and virtues are hereditary" (168). In another sentence (39), he even referred to the "poverty instincts" of the lower classes, which "survive by means of natural characters that appeared in the animal world, and reappear with augmented influence in all peoples forced to depend upon each other for safety and race continuity." Ultimately, Patten arrived at an intermediate position in what may be considered the most legible if his statements:

Many qualities are inherited, but the number is smaller than it was thought to be, and many of them may be readily suppressed by the action of the environment in which men live, so that they do not show themselves for long periods in a particular family or a given race. This curtailment of the force of physical heredity gives more power to the acquired qualities handed on from generation to generation as a social tradition. (204)

This allowed Patten, as a reformer, to downplay (without denying it) the role of physical heredity: "[a] physical inheritance, simpler than we thought, is ours at birth; but there is a larger and increasingly important social heredity which must be constantly renewed through the conscious efforts of parents and teachers" (204-205).

6. Patten's anti-racialist stance becomes even more manifest if one looks at his views on immigration. Interestingly, Leonard includes Patten among those who opposed immigration on both racial and economic grounds. Some passages from Patten's early works do support this interpretation. In The Consumption of Wealth, for instance, Patten $(1899,26)$ complained that "the tendencies of American civilization are covered up by the presence of those who have not been 
influenced by the American environment." The problem, for Patten as for many other progressives, was the lower standard of living of the new immigrants. "If our workmen in the future are to live wholly upon cheap coarse foods," he warned (50), "they will not be the descendants of the present American stock, but of the lower races of Europe and Asia." The transition towards a universal condition of abundance, he continued (68), is a "heartless one" which "will create much friction between the different classes in society if the immigration of cheap men is not restricted." Patten reveals an even harsher anti-immigration stance in The Theory of Social Forces:

When the Chinese or the Indians are admitted into a higher civilization, they do not compel progress either for it or for themselves. They tend to break down not only the habits which made them useful parts of their own civilization, but also those habits and ideals of the higher civilization upon which its future progress depends. The earth has but one general environment and can bring to perfection but one type of man. Attempts to preserve lower types of men, or to bring them into organic relations with higher types, tend to make a society static and thus check its progress. They may even result in social degeneration through the introduction of new temptations, vices and crimes. $(1896,131-132)$

In a following passage (1896, 148: quoted in Leonard 2016, 130) he added: "The friends of American institutions fear the ignorant immigrant, and the workingman dislikes the Chinese. Every one is beginning to differentiate those with proper qualifications for citizenship from some class or classes which he wishes to restrain or to exclude from society."

A systematic scrutiny of Patten's later works, however, shows a quite decisive shift in his views on immigration-and this appears to be in line with our previous discussion of Patten's 
position on poverty. In The New Basis of Civilization, the work which best represents his change in perspective, Patten did not see anymore immigrant workers as a threat and praised unions for overcoming differences of race and religion. It is the "union card," he wrote (1907, 112-113), "which brings to the terrorized immigrant a sense of fellowship and of security." But it was in 1911 that Patten's pro-immigration stance became far more outspoken, after the publication of the Dillingham Immigration Commission's massive report in forty-one volumes. The data gathered by the Commission contributed to crystallize the (already popular) dichotomy between "old" and "new" immigrants. The former group, composed of northern and western European immigrants, was described as "a movement of settlers, who came from the most progressive sections of Europe for the purpose of making themselves a home in the new world." They had entered a wide range of occupations, settled throughout the country, and posed no problem of assimilation. By contrast, the new immigration was depicted as a "movement of unskilled laboring men who have come, in large part temporarily, from the less progressive and advanced countries of Europe." Mostly concentrated in large urban centers, these new arrivals were considered less assimilable in American society and seen as inferior in education, ability, and genetic make-up. Among the recommendations proposed by the Commission were a literacy test, a permanent ban on Asian immigration, legislation restricting the further admission of unskilled labor, and some sort of ethnically discriminating quota system (Zeidel 2004; Leonard 2016).

Patten decided to attack the findings and recommendations of the Commission immediately after its report was delivered to Congress - he did so in a public letter he sent to the editor of the Survey (who at the time was Devine) and which was published in the February 1911 issue. ${ }^{19}$ Patten could not find a connection between the copious facts produced by the Commission and the

\footnotetext{
19 This is significant because, as Leonard $(2016,158)$ points out, The Survey was "vigorously restrictionist" and it had immediately endorsed the Commission's recommendation of immigration restriction in general and the literacy test in particular. Devine (1911), for instance, called opposition to immigration restriction treasonous, explicitly worrying about racial mongrelization. See also Lee 1911; and Kellogg 1911.
} 
conclusions drawn in the report. There is no evidence, he argued (1911c, 886), that "any large class of immigrants are undesirable or differ in any fundamental respect ... from those who had previously come," nor it is convincingly demonstrated that "an educational test would give a more desirable class of immigrant than those it would exclude." According to Patten, "the only solution of existing evils lies in the elimination of race distinctions" and for this end the "free movement of population" becomes essential. "The immigrant brings labor when he comes to us," he explained; "he takes back ideas when he returns." In this way, "he helps to transform America through its material progress and Europe through emancipation from its load of antiquated customs, habits, and ideals."

Patten continued reiterating the notion that an increased standard of living is the only avenue whereby immigrants, irrespective of their racial origin, will be assimilated into American society. For many aspects, we find here Patten aligned with those who advocated the "Americanization" of the immigrant-a distinctly ethnocentric stance that took for granted the superiority of American institutions and often dictated either conformity or exclusion (Gleason 1980). ${ }^{20}$ According to Patten, however, there is nothing inherently superior to American ideals-if not the fact that America has been the first to experience the transition towards an economy of abundance-nor European immigrants are prevented by "blood" or any racial characteristic from learning them when they come to America:

There is no ideal America that does not involve an ideal Europe. To hem ourselves in or to shut others out is to lose the ideal ourselves and bring on race conflicts instead of international unity. Nor are there American ideals in any distinct local sense. All ideals are social, good for every land, race, and age. The only reason for giving them a specific

\footnotetext{
${ }^{20}$ At this stage of the discussion the reader will not be surprised to find Patten advancing opposite views as to the need to fully "Americanize" immigrants. In his Social Basis of Civilization (1907, 131), for instance, he had written that immigrant's traditions were "as valuable as our own" and if "we are skillful enough to preserve them in our lore the gain will be no less theirs than ours."
} 
name is to tell where they originated. Greek ideals have no peculiar fitness for Greece, but can thrive anywhere if conditions favor them. They represent a stage in the forward movement of thought which happened to express itself in Greece. So is it with American ideals. We want the honor of being the nation where the new civilization first works out its legitimate consequences. But these new ideals are not to be confined to American soil nor guarded against exportation. Our race has exactly the same blood as other white races; our ideals are theirs or will soon be. $(1911 c, 886)$

"No policy of restriction can check the spread of ideas or prevent the blending of all races into one," was Patten's final message to the Commission (see also Patten 1915). ${ }^{21}$

A similar anti-nativist stance emerges in Patten's views on "race suicide," the then popular mantra that the native stock would ultimately vanish because of immigrants' higher fertility. Patten did express vivid concerns about declining birthrates among American families $(1910,1912 d)$ and in his recollections Tugwell $(1923,201)$ even ventured that it was Patten who coined the very expression "race suicide." 22 Unlike the most outspoken nativists of the period, however, Patten did not establish a causal nexus between increasing immigration and the decline in American birthrates, nor did he phrase his argument in racialist terms. According to Patten (1910), native fertility declined in response to the higher standard of living, in the sense that reproduction was "traded" for consumption. As he explained in detail to a local newspaper:

The change that has come to our birthrate has affected both sexes in the matter of American parents. You see a young couple in an automobile. They are a young married

\footnotetext{
${ }^{21}$ One referee has pointed out the inherent racism of Patten's reference to the unity of "white racer." This is certainly a high degree of ambiguity in this passage although, as we have shown above in connection to his discussion of the "Negro Race," Patten revealed no taint of biological determinism as to their status.

${ }^{22}$ The term "race suicide" is usually attributed to Ross. See Ross (1901).
} 
pair, and they have their auto. Well, rely upon it, they have been saving somewhere to get it; they have been sacrificing something for the sake of owing it. The car is something both of them wanted; they have agreed, with equal readiness, to make the sacrifice of what they desired less for the sake of possessing what they desire more. The city life of the present day puts a lot of expenditures before the people; all of them desire all they can get. Now, where can they cut down? In nine families out of ten, they cut down on children. ("\$1,000 A Year is the Race Suicide Line" 1912)

Patten did not suggest any specific remedy to the problem, just observing that "this condition is a common one all over the civilized world." Nonetheless, in a significant passage of The Social Basis of Religion (1911a, 211), he ventured that "[p]rosperity checks the birth rate and promotes race suicide to such a degree that if new races cannot be raised to take the place of those dying out, there will be a decline in civilization to the level existing before the rise of Christianity." This would require a new impetus in the process of evangelization:

All of the earlier missionary efforts will be in vain unless methods are devised to arouse new classes, races and nations with the same success with which our ancestors were awakened in earlier epochs by the prevailing forms of religious propagation. If laborers remain outside the church, if immigrants are not assimilated into our national life, or if we fail to do for Africa, India and China what the early Christian missions did for our German ancestors, a slow but certain death awaits the church, no matter what may be its success in other fields. No headway is possible unless there come modifications of attitude and doctrine that will make the church a force among races and classes it at present fails to reach. (211-212) 
What is relevant here is again the distance between Patten and the more racialist and nativist oriented of his contemporaries. Patten did not see race suicide as a biological problem, nor did he blame immigration for it, and his prospective solution to the problem was socially inclusive rather than exclusive. ${ }^{23}$

7. A few final words should be spent on Patten's position on women. As Francis Tyson (“Memorial to Former President Simon N. Patten" 1923, 292) pointed out in his recollections, throughout his life Patten was a "consistent and thorough-going feminist." Among Progressive Era reformers, in fact, Patten was among the most outspoken critics of the then conventional family ideal of an independent male breadwinner in the marketplace and a dependent female homemaker in the home. "The master-key to family unity is not found in the division of function into supporting husband and supported wife," nor is the working woman's femininity being sacrificed on the altar of industrial capitalism, he held $(1904,1248)$ in a controversial article which provoked a flow of indignant reactions. This, we feel compelled to note once again, places Patten on the opposite side with respect to those who saw the employed woman as a social, economic, and even biological threat. As documented by Leonard, with due differences in style and emphasis, leading figures of the period such as Ely, Fisher, Commons, and Henry R. Seager all justified exclusionary labor legislation for women on the grounds that it would both protect male workers from the "undercutting" competition of women and ensure that women could better carry out their maternal duties.

\footnotetext{
${ }^{23}$ Patten $(1911 a, 240)$ was extremely clear as to the preeminently cultural nature of race suicide: "Our culture is not due to our racial ancestors, but to Greece, Rome and other ancient civilizations. Culture is thus objective and may exist along with a decline in physical traits. In fact, race suicide and culture are so intimately connected that the one rarely exists without the other."
} 
By contrast, Patten encouraged women to work outside the home, and on more than one occasion he did not hesitate to openly attack the idea that "the wife must remain under her husband's roof because he is the natural money-maker for his family" (1244). ${ }^{24}$ As he saw it, industrialization had made traditional domestic occupations inefficient and unproductive, reducing their economic value to the family. "The truth" - he wrote-"is that woman's work has been taken away from her home, and she must follow it out into the world" (1246). Patten rejected the then popular view that women should accept a lower wage since their wages needed only to support themselves, while men's wages needed to support a family. Writing in The Theory of Prosperity, Patten $(1902,229)$ had already advocated the "right of women to income" on the ground that "no society is safe, nor can it be moral and progressive, until women ... have independent incomes." Later in his life he went a step further asserting a principle of equal pay for equal work by women and men. "Where women and men do the same work their pay shall be the same," he stated (1919, 47). ${ }^{25}$ In addition, "[i]f women are excluded from unsuitable occupations, corresponding occupations shall be reserved for them subject to such regulations as their health and public welfare demand." For Patten economic independence was the only road to women's emancipation-an emancipation which implied complete equality between the sexes. As he explained:

the city home of the immediate future will be unique in that it will be built by two who are educated, side by side, in the public school, whose industrial careers are side by side in the factory, whose plans of life, formed by the same city outlook, have resulted in like powers and parallel interests. For such a pair the logical home will be an equalized expression of their interrelated pasts and their approximating futures. (1904, 1248)

\footnotetext{
${ }^{24}$ Unsurprisingly, Patten's pro-women stance caught the attention of the national press (see, for instance, "Professors Say Wives Should Earn Wages" 1904).

${ }^{25}$ Arguments for equal pay for equal work were atypical in the Progressive Era, even among female reformers. See Figart, Mutari and Power 2002 for an excellent reconstruction of the debate.
} 
When the traditional boundaries which have impeded women's labor-force participation are broken down, he insisted in a later writing (1912d, 260), "there is no equilibrium that does not involve the full equality of women."26

8. Time has arrived now to draw some conclusions. This note has provided further support to Leonard's own characterization of Patten as a special case among the roster of progressives he discusses in his book. Certainly, there are important affinities between Patten and the core of "illiberal reformers" which cannot be ignored-it is undeniable that Patten was as critical of classical liberalism as virtually all of his contemporaries, that in his early works he identified social process with the natural elimination of the unfit, and that in some instances he flirted with eugenics. As our reconstruction reveals, however, Patten's ideas evolved over time and, albeit retaining an irreducible degree of ambiguity, acquired a somewhat different character with respect to those advanced by the harshest exponents of Progressive Era illiberalism (as defined by Leonard). Patten represents a special case in several respects. First, Patten was far more cautious than his contemporaries in placing technical expertise above democratic deliberation, and his writings reveal little trace of the elitist self-conception of the expert which can be found in many figures of his day. Instead of rejecting democracy for technocratic coercion, Patten gradually came to see group divides and class politics ultimately as barriers that inhere in the constraints of the "pain economy." In turn, he argued, the social interdependences emerging spontaneously out of industrial capitalism could be used to create a new sense of social cooperation beyond traditional hierarchies.

\footnotetext{
${ }^{26}$ Patten was also very active in the campaign for female suffrage, "appearing in parades under the banner of 'Votes for Women' and responding to all the ridicule and reproach he encountered with the calm conviction that time would demonstrate the justice of this cause" (Meyerson and Winegrad 1978, 151).
} 
Second, in his thinking on poverty, Patten moved from a Social Darwinist notion of the "unfit" and the related concern for the "dysgenic" consequences of technological advances-via the differentiation between poverty and misery - to a stance that linked moral improvement and racial emancipation to the redistribution of material goods ("income altruism"). Significantly, such a change in the conception of poverty made Patten the object of severe criticism from Carver and Richmond, two figures with both their feet well in the illiberal camp. Patten's view on immigration shifted likewise. He gradually abandoned the view that immigration was a threat to abundance because of the importation of cheap labor and of "new immigrants" as civilizational impediments. Instead, he began to see immigrants in terms of their "work" as contributors to an abundance economy, rising living standards, and subsequent ethical transformations. As we showed, he was among the few who publicly rejected the Dillingham Commission's recommendations of literacy tests, exclusion of undesirable immigration, quotas, and restrictions on unskilled immigrants. In the same, vein, Patten emerges as an early critic of traditional gender roles. In his view, abundance undermines the concept of the male breadwinner and female homemaker because of the inefficiency of traditional domesticity. In turn, he linked social progress to women entering the workplace and gaining pay equality.

Certainly, and with this we conclude, Patten never fully emancipated himself from some of the "illiberal" (à la Leonard) tendencies pervading progressivism and, we may add, Progressive Era reform impetus in general. This irreducible ambiguity in Patten's thought, a sort of inner tension, becomes manifest in his view $\mathrm{n}$ eugenics-which admit that can be prone to different interpretations. Patten did in fact acknowledge in several occasions that the inherited characteristics of a population might be a factor affecting social well-being, and there is certainly an irreducible degree of ambivalence in some of his assertions. Even in the Social Basis of Civilization $(1907,63)$, he affirmed that the transition towards abundance will be made possible "through the 
union of a sound physical heredity and a progressive social heredity." Yet, in spite of these concerns over the biological quality of individuals, Patten did not place heredity at the center of his reform preoccupations. It is to "social heredity "which he assigned priority and in his mature works he was consistent in rejecting the possibility of grounding social policy in biological considerations. "Biology may startle," he wrote in his rejoinder to Carver (1912b, 65), but it has "no cure for the underlying evils blocking human progress." A few years later $(1916,51)$, he was still disposed to concede that "[e]ugenics might give us a different man with other dominant and recessive traits," but, he immediate added, "to social changes we must look ... for the stability of those institutions that promote culture, cooperation, and general prosperity." 
References

“\$1,000 A Year is the Race Suicide Line. Professor Simon N. Patten Finds that Americans Don't Want Babies So Much as Automobiles When they Gain Prosperity." 1912. The Times dispatch Richmond (November 24).

Bateman, Bradley W. 2017. Review of Illiberal Reformers: Race, Eugenics, and American Economics in the Progressive Era by Thomas C. Leonard. History of Political Economy 49(4): 717-721.

Boyer, Paul S. 1978. Urban Masses and Moral Order in America, 1820-1920. Cambridge: Harvard University Press.

Bushee, Frederick A. 1903. Ethnic Factors in the Population of Boston. Publications of the American Economic Association 4(2): 1-171.

Calkins, Gary N. 1903. Review of Heredity and Social Progress by Simon N. Patten. Political Science Quarterly 18(3): 539-541.

Carver, Thomas N. 1911. Review of The Social Basis of Religion by Simon N. Patten. American Economic Review 1(4): 790-794.

- - . 1912. The Religion Worth Having. Boston: Houghton Mifflin.

Commons, John R. 1907. Races and Immigrants in America. New York: The Chautauqua Press.

Devine, Edward T. 1907. The New Basis of Civilization: Patten. Charities and the Commons XVIII(May): 135-136.

- - 1911. Selection of Immigration. Survey, 25(February 4): 715-16.

Dorfman, Joseph. 1949. The Economic Mind in American Civilization, 1865-1918. New York: Viking Press.

Figart, Deborah M., Ellen Mutari and Marilyn Power. 2002. Living Wages, Equal Wages: Gender and Labor Market Policies in the United States. London: Routledge. 
Fiorito, Luca and Cosma Orsi. 2017. "Survival Value and a Robust, Practical, Joyless Individualism": Thomas Nixon Carver, Social Justice, and Eugenics. History of Political Economy 49(3): 469-495. Fox, Daniel M. 1967. The Discovery of Abundance: Simon N. Patten and the Transformation of Social Theory. Ithaca: Cornell University Press.

Franklin, Donna L. 1986. Mary Richmond and Jane Addams: From Moral Certainty to Rational Inquiry in Social Work Practice. Social Service Review 60(4): 504-525.

Furner, Mary. 2018. Not All II-liberal: Academic Reform Thought in the Long Progressive Era. Research in the History of Economic Thought and Methodology 35B: 325-343.

Gleason, Philip. 1980. American Identity and Americanization. In Harvard Encyclopedia of American Ethnic Groups, edited by Stephan Thernstrom, Ann Orlov, and Oscar Handlin. Cambridge: Belknap Press: $31-85$.

Hofstadter, Richard. 1955. The Age of Reform: From Bryan to F.D.R. New York: Knopf. Hollander, Jacob H. 1914. The Abolition of Poverty. New York: Houghton Mifflin.

Hunt, Emery K. 1970. Simon Patten's Contribution to Economics. Journal of Economic Issues 4(4): $38-55$.

Kellogg, Paul U. 1911. An Immigration Labor Tariff. Survey XXV(January): 529-531.

Kennedy, Angie C. 2008. Eugenics, "Degenerate Girls," and Social Workers During the Progressive Era. Affilia: Journal of Women and Social Work 23(1): 22-37.

LaJeunesse, Robert M. 2010. Simon Patten's Contributions to the Institutionalist View of Abundance. Journal of Economic Issues 44(4): 1029-1044.

Lee, Joseph. 1911. The Restriction Recommendations. Survey XXV(January): 524-526.

Leonard, Thomas C. 2003. More Merciful and Not Less Effective: Eugenics and American Economics in the Progressive Era. History of Political Economy 35 (4): 709-734. 
- - - 2005a. Mistaking Eugenics for Social Darwinism: Why Eugenics Is Missing from the History of American Economics. History of Political Economy 37 (supplement): 200-233.

- - 2005b. Retrospectives: Eugenics and Economics in the Progressive Era. Journal of Economic Perspectives 19(4): 207-224.

- - . 2009. American Economic Reform in the Progressive Era: Its Foundational Beliefs and Their Relationship to Eugenics. History of Political Economy 41(1): 109-141.

- - . 2011. Religion and Evolution in Progressive Era Political Economy: Adversaries or Allies? History of Political Economy 43(3): 429-4

- - . 2016. Illiberal Reformers: Race, Eugenics, and American Economics in the Progressive Era. Princeton: Princeton University Press.

Levy, David M., Sandra J. Peart, and Margaret Albert. 2012. “Economic Liberals as Quasi-Public Intellectuals: The Democratic Dimension." Research in the History of Economic Thought and Methodology 30 (B): 1-116.

"Memorial to Former President Simon N. Patten." 1923. American Economic Review 13(1): 257-293. Meyerson, Martin and Dilys P. Winegrad. 1978. Gladly Learn and Gladly Teach: Franklin and His Heirs at the University of Pennsylvania, 1740-1976. Philadelphia: University of Pennsylvania Press.

Patten, Simon. N. 1885. The Premises of Political Economy. Philadelphia: J. B. Lippincott.

- - . 1889. The Consumption of Wealth. Philadelphia: Publications of the University of Pennsylvania. Series in Political Economy and Public Law, no. 4.

- - . 1896. The Theory of Social Forces. Annals of the American Academy of Political and Social Science 7(10): 1-151.

-- 1899. The Development of English Thought. New York: MacMillan.

- - 1902. The Theory of Prosperity. New York: Macmillan. 
- - 1903. Heredity and Social Progress. New York: Macmillan.

- - . 1904. Young Wives in Industry. Independent LVII(December): 1244-1249.

- - . 1907. The New Basis of Civilization. New York: Macmillan.

- - . 1910. The Crisis in American Home Life. Independent LXVIII(February): 342-346.

- - . 1911a. The Social Basis of Religion. New York: Macmillan.

- - . 1911b. The Laws of Environmental Influence. Popular Science Monthly 79(October): 396-

402.

- - . 1911c. Construction Vs. Distribution. Survey 24(February 18): 866-867.

- - . 1912a. The Reconstruction of Economic Theory. Philadelphia: The American Academy of Political and Social Science.

-- . 1912b. Theories of Progress. American Economic Review 2(1): 61-68.

- - - 1912c. Types of Men. Popular Science Monthly 80 (March): 273-279.

- - 1912d. Shall Woman Be Tool or Partner? Twentieth Century Magazine VI(July): 254-262.

---. 1915. Becoming Americans. Open Court XXIX(7): 385-393.

--- 1916. Culture and War. New York: Huebsch.

- - 1919. Making National Debts National Blessings. Annals of the American Academy of Political and Social Science 82: 39-51

-- - 1922b. Mud Hollow. Philadelphia: Dorrance.

“Professors Say Wives Should Earn Wages." 1904. New York Times April 11.

Richmond, Mary E. 1903. Friendly Visiting Among the Poor. New York: Macmillan.

- - 1907. The Good Neighbor in the Modern City. Philadelphia: J. B. Lippincott Company.

- - 1917. Social Diagnosis. New York: Russell Sage Foundation.

Ross, Edward A. 1901. The Causes of Race Superiority. Annals of the American Academy of Political and Social Science 18: 67-89. 
Schäfer, Axel R. 2000. American Progressives and German Social Reform, 1875-1920. Stuttgart: F. Steiner Verlag.

- - . 2004. German Historicism, Progressive Social Thought, and the Interventionist State in the United States since the 1880s. In Markets in Historical Context: Ideas and Politics in the Modern World, edited by Mark Bevir and Frank Trentmann. Cambridge, MA: Cambridge University Press, 145-169.

Tugwell, Rexford G. 1923. Notes on the Life and Work of Simon Nelson Patten. Journal of Political Economy 31(2): 153-208.

Vincent, George E. 1907. Review of The New Basis of Civilization by Simon N. Patten. Political Science Quarterly (22)4: 741-743.

Woods, Frederick A. 1910. Laws of Diminishing Environmental Influence. Popular Science Monthly 76(April): 313-336.

Zeidel, Robert F. 2004. Immigrants, Progressives and Exclusion Politics: The Dillingham Commission 1900-1927. DeKalb: Northern Illinois University Press. 